\title{
Pemanfaatan Visual Literacy melalui Gambar untuk Memotivasi Siswa Belajar Bahasa Inggris
}

\author{
R Agus Budihartoํㅡ, Laili Amalia², Fujiono ${ }^{3}$ \\ 1,2,3 Universitas Madura
}

\begin{abstract}
Article History ABSTRACT
Received 09.03.2019

Received in revised form 08.04.2019

Accepted 21.07.2019

Available online 20.08.2019

USING VISUAL LITERACY THROUGH IMAGES TO MOTIVATE STUDENTS

TO LEARN ENGLISH. Existing in an image-rich world, as school students currently experience, does not mean that they naturally possess right visual literacy aptitudes as when they see an object (such as a picture), they just see what they see, they do not possess a considerable capability to understand, interpret, discover a meaning from an object or information they see. For that reason, students are supposed to possess visual literacy to perform that. Given the importance of utilizing visual literacy through a picture to motivate students in learning English, the writer of this article has the initiative to carry out community service to first-grade students of MTS Qurrotul Uyun. This community service discusses the utilization of visual literacy through colored pictures as a pedagogical tool, which can provide a precious and motivating resource for the students to learn English. The result of this community service suggests that English learning through colored pictures is potential to make the MTS Qurrotul Uyun first grade students motivated in learning pronunciation, speaking, and grammar. They feel that English learning through colored pictures in the classroom is more appealing and pleasurable as the pictures can both catch their mind attention and facilitate them to learn. Moreover, the colored pictures can make the MTS Qurrotul Uyun first grade students motivated and more involved actively in English learning.

KEYWORDS: Colored Pictures, Grammar, Pronunciation, Speaking, Visual literacy.
\end{abstract}

This is an open access article distributed under the terms of the Creative Commons Attribution 4.0 International License, which permits unrestricted use, distribution, and reproduction in any medium, provided the original work is properly cited. (c) 2019 R Agus Budiharto, Laili Amalia, Fujiono.

\section{PENDAHULUAN}

Hadirnya berbagai media visual di dunia pendidikan pada jaman digital ini tidak dapat di hindarkan. Para siswa sekolah dengan mudahnya dapat meakses informasi visual dengan cepat, seperti melihat peristiwa atau berita dunia melalui youtube, melihat berbagai referensi buku melalui gadget android, atau melihat berbagai karya tulisan ilmiah

${ }^{1}$ Corresponding author: Program Studi Pendidikan Bahasa Inggris, FKIP Universitas Madura; Jl. Raya Panglegur KM. 3,5 Pamekasan, Madura, Indonesia; Email: congbudiharto@gmail.com 
melalui layanan internet. Memang saat ini siswa sekolah dihadapkan pada jaman yang serba berhubungan dengan informasi visual namun bukan berarti mereka mempunyai literasi visual yang baik. Karena pada umumnya ketika melihat objek atau informasi, mereka hanya sebatas melihat saja tanpa memiliki kemampuan untuk bisa memahami, menginterpretasikan, menemukan arti terhadap informasi yang mereka lihat. Kemampuan ini kemudian lazim dikenal dengan istilah "Visual Literacy" (VL).

Menurut Yenawine (2005) visual literacy adalah kemampuan untuk menemukan arti pada gambar yang melibatkan proses kemampuan kognitif. Berkenaan dengan ini Burmark (2002) menerangkan bahwa literasi utama di abad 21 ini adalah literasi visual, seperti gambar, grafik, foto dan lain-lain. Burmark juga menyatakan mampu membaca dan menulis saja tidak cukup. Siswa harus belajar memproses kata dan gambar. Ini menunjukkan bahwa visual literacy harus dipelajari dan mempunyai peranan sangat penting terutama di dunia pendidikan. Namun demikian, kurangnya perhatian pedagogik dari guru untuk memanfaatkan visual literacy pada saat proses belajar mengajar sedang berlangsung adalah suatu permasalahan yang cukup serius terutama pada saat menjelaskan suatu materi pelajaran, terlebih materi pelajaran yang di anggap sangat sulit untuk dimengerti dan dipahami oleh siswa didik, seperti materi pelajaran bahasa inggris sebagai bahasa asing bagi siswa Indonesia.

Sesuatu yang penting dan perlu diperhatikan oleh para guru bahasa Inggris khususnya ketika mengajarkan materi bahasa inggris pada siswa di kelas dengan cara menggunakan banyak penjelasan verbal yang dapat mengkonsumsi banyak waktu atau dengan cara membuat latihan-latihan yang lazim di gunakan seperti: memberikan soal pilihan ganda, soal benar atau salah, dan memberikan soal untuk mengisi titik titik yang kosong dengan jawaban yang benar adalah suatu cara mengajar yang memang diperlukan namun menjenuhkan dan tidak menarik bagi siswa. Karena siswa akan menjadi pasif dan tidak termotivasi untuk terlibat dalam pembelajaran. Oleh karena itu, seorang guru bahasa Inggris perlu memiliki strategi pedogogik yang menarik dan menyenangkan saat menjelaskan suatu materi pelajaran agar siswa bisa termotivasi dan terlibat aktif dalam belajar bahasa Inggris.

Mengingat belajar bahasa inggris bagi siswa penutur bahasa Indonesia bukanlah sekedar belajar hal-hal yang berhubungan dengan masalah mata pelajarannya saja akan tetapi siswa juga harus terlibat aktif berpatisipasi selama proses kegiatan pembelajaran berlangsung di kelas. Hal yang demikian tentunya tidak mudah untuk diwujudkan agar siswanya tetap terlibat aktif dan tetap berpartisipasi selama mengikuti pelajaran di kelas, apalagi ketika siswanya mendapatkan topik pelajaran yang sangat sulit untuk di pahami yang bisa berdampak pada minat dan motivasi belajar siswa. Salah satu aspek yang paling penting dalam kegiatan pembelajaran yang harus diperhatikan dan diterapkan oleh praktisi pendidikan atau guru adalah memotivasi minat belajar siswa agar untuk memperoleh suatu pengetahuan dapat terealisasi. Karena dalam proses memperoleh suatu pengetahuan, unsur motivasi sangat diperlukan karena mempunyai peranan yang sangat penting dalam suatu kegiatan pembelajaran.

Cook (2000) menyatakan bahwa ada tiga (3) faktor utama yang dapat mempengaruhi pemerolehan suatu pengetahuan: umur, kepribadian dan motivasi, dan diantara tiga faktor tersebut, motivasi merupakan faktor yang sangat penting dan sangat mempengaruhi keberhasilan individu dalam meraih prestasinya. Tanpa memiliki motivasi, siswa tidak akan mungkin mampu untuk meraih prestasi pembelajarannya. 
Selain itu, visual aids seperti gambar sebagai pendukung alat pedagogik dalam suatu pembelajaran juga mempunyai peranan penting karena gambar dapat menarik perhatian pikiran atau konsentrasi siswa terhadap informasi visual yang mereka lihat sehingga nantinya mereka akan memiliki kemampuan untuk mengungkapkan dan mendeskonstruksikan kode-kode dari sebuah gambar secara aktif, dan tidak menjadi siswa yang pasif. Harris dan Caviglioli (2003) menegaskan bahwa visual aids seperti gambar merupakan alat pengingat yang efektif yang dapat meningkatkan suatu pemahaman. Berdasarkan uraian tadi dan uraian sebelumnya, dan mengingat pentingnya pemanfaatan VL melalui gambar untuk memotivasi siswa dalam belajar bahasa Inggris maka penulis memandang perlu untuk melaksanakan kegiatan pengabdian masyarakat kepada siswa di MTS Qurrotul Uyun, salah satu sekolah swasta yang terletak di desa Tentenan Kec Larangan Pamekasan-Madura Jawa Timur.

\section{METODE PELAKSANAAN}

Siswa MTS Qurrotul Uyun, khususnya kelas satu, mengalami banyak kesulitan dalam belajar bahasa Inggris. Beberapa kesulitan utama mereka adalah ketika melafalkan kata (pronunciation) ketika berbicara (speaking) dan kesulitan ketika menyusun kata untuk menjadi kalimat bahasa Inggris yang benar (grammar). Mereka sering kali salah atau tidak tahu ketika di suruh untuk mengucapkan kata bahasa Inggris ataupun ketika disuruh menyusun kata dalam kalimat bahasa Inggris. Hal ini membuat mereka seringkali merasa malu, malas, dan tidak termotivasi untuk mempraktikkannya lagi. Dan dari hasil observasi yang dilakukan sebelumnya diketahui juga guru mapel bahasa inggris mereka masih cenderung menerapkan cara konvensional yang tidak di dukung oleh visual aids saat menjelaskan suatu materi. Fenomena ini menginspirasikan penulis untuk memanfatkan visual literacy melalui gambar sebagai metode pengajaran dan sebagai sumber informasi pengetahuan dalam melaksanakan kegiatan pengabdian masyarakat.

Adapun kegiatan pelaksanaan pengabdian masyarakat ini dilakukan dengan melalui tahapan - tahapan sebagai berikut:

Articulation and Imitation

Pada tahapan pertama ini, penulis pengabdian masyarakat menggunakan power point untuk memperlihatkan gambar pada siswa kelas satu yang disertai dengan katakata bahasa inggris. Penulis melafalkan kata-kata bahasa Inggris dengan tepat dan jelas tanpa menterjemahkan kata tersebut ke bahasa Indonesia. Ini dilakukan agar siswa lebih fokus dan paham pada ketepatan bunyi kata per kata (pronunciation). Kemudian penulis menyuruh siswa untuk menirukan kata-kata bahasa Inggris yang telah di ucapkan dengan tepat oleh penulis dengan melafalakannya secara bersama-sama.

Repetition and Reading aloud

Pada tahapan kedua, penulis menginstruksikan siswa untuk memperhatikan gambar yang ada pada power point dengan seksama. Gambar tersebut tidak diberi katakata bahasa Inggris agar siswa termotivasi untuk mengartikan atau mendiskripsikan gambar dengan menggunakan kata bahasa Inggris (speaking). Penulis memberikan pujian bagi siswa yang bisa menjawab dengan menggunakan kata bahasa Inggris dengan benar dan memberikan koreksi bagi yang jawabannya salah. Kemudian gambar yang semula 
tidak ada kata-kata bahasa Inggris, di berikan kata-kata bahasa Inggris yang sesuai dengan arti gambar.

Untuk memperkuat daya ingat siswa terhadap pengetahuan kata bahasa Inggris yang terdapat pada gambar, penulis menyuruh siswa secara bersama-sama mengulangi kata-kata untuk di ucapkan lagi setelah mendengarkan ucapan kata dari penulis terlebih dahulu kemudian menyuruh siswa secara individu untuk membaca kumpulan kata (kalimat) tersebut dengan keras, jelas dan tepat, agar siswa memiliki kepercayaan diri dan terlibat aktif berpartisipasi dalam kegiatan pembelajaran praktik speaking.

Recombination

Pada tahapan ketiga ini, dengan power point penulis memeperlihatkan gambar yang disertai dengan kalimat bahasa Inggris dalam bentuk pertanyaan. Siswa di suruh untuk menjawab pertanyaan yang berhubungan dengan apa yang mereka lihat di gambar. Kemudian jawaban mereka disuruh di buat dalam bentuk pernyataan atau kalimat positif dengan cara menggabungkan lagi beberapa kata yang ada di kalimat pertanyaan dengan menggunakan aturan tata bahasa Inggris yang benar (grammar). Kemudian penulis juga memberikan tambahan jenis- jenis kata keterangan waktu (adverb of time) pada kalimat yang telah di susun dengan benar oleh siswa agar siswa mendapatkan pengetahuan jenisjenis tenses bahasa Inggris beserta pola-polanya.

\section{HASIL DAN PEMBAHASAN}

Pada dasarnya siswa kelas satu MTS Qurrotul Uyun telah memiliki pengetahuan bahasa Inggris ketika mereka belajar di sekolah dasar namun kemampuan bahasa inggris mereka belum begitu maksimal di karenakan ada beberapa faktor yang mempengaruhinya, di antaranya adalah faktor kesulitan memahami bahasa Inggris dan faktor motivasi dari siswa sendiri. Untuk menangani kesulitan atau permasalahan yang mereka hadapi agar mereka termotivasi dalam belajar bahasa Inggris, penulis melaksanakan pengabdian masyarakat "Pemanfaatan Visual Literacy Melalui Gambar Untuk Memotivasi Siswa Belajar Bahasa Inggris" yang dilaksanakan pada hari Sabtu tanggal 2 Mei 2019, dengan tujuan pelaksanaan kegiatan pengabdian masyarakat ini dapat: 1) memotivasi siswa belajar pronunciation; 2) memotivasi siswa belajar speaking;3) memotivasi siswa belajar English grammar

\section{Memotivasi Siswa Belajar Pronunciation}

Dalam memotivasi siswa kelas satu MTS Qurrotul Uyun belajar tentang bagaimana cara melafalkan atau mengucapkan kata bahasa Inggris dengan benar dan tepat, penulis memperlihatkan sebuah power point yang terdapat sebuah gambar warna, dimana gambar tersebut menggambarkan tentang seorang anak kecil yang sedang bermain di kolam renang seperti yang dapat di lihat pada Gambar 1. Dan di bawah gambar tersebut, penulis memberikan kata-kata bahasa Inggris. Saat melafalkan kata-kata bahasa Inggris, penulis sengaja tidak menterjemahkan kata-kata tersebut ke dalam bahasa Indonesia, agar para siswa lebih memfokuskan pada pendengaran mereka saat mendengarkan pelafalan kata bahasa Inggris dari penulis sehingga mereka akan memahami ketepatan bunyi kata per kata dan mengetahui dengan jelas bagaimana melafalkan kata yang tepat sesuai dengan system pelafalan bahasa Inggris. 


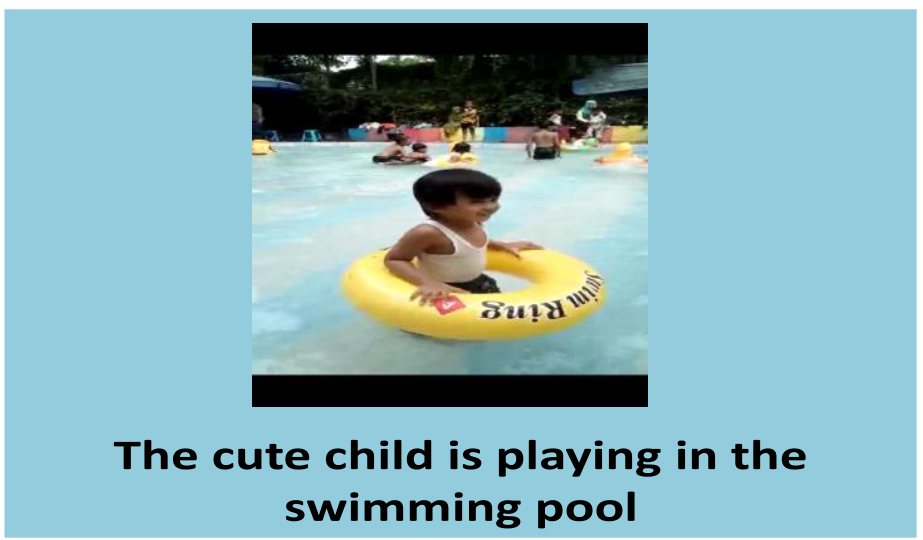

Gambar 1. Contoh Gambar yang disertai Dengan Kata-Kata Bahasa Inggris untuk Memotivasi Siswa Belajar Pronunciation

Pada kegiatan ini, penulis terlebih dahulu melafalkan kata per kata dengan jelas dan tepat, kemudian para siswa kelas satu disuruh untuk menirukan lafalan penulis dengan melafalkannya secara bersama-sama. Seperti melafalkan:

/ðə/ untuk the,

/kju:t/ untuk cute,

/tfarld/ untuk child,

/Iz/ untuk is,

/pleijin/ untuk playing,

/rn/ untuk in,

/ðə/ untuk the,

/swimin/ untuk swimming, dan

/pu:1/ untuk pool.

Setelah selesai melafalkan kata per kata, penulis melafalkan keseluruhan kata: “The cute child is playing in the swimming pool" seperti yang ada pada Gambar 1 dengan melafalkan:

“/ðə/ /kju:t/ /tfarld/ /ı/ /plerjın/ /ın/ /ðə/ /swımın/ /pu:l/"

Kemudian siswa disuruh untuk menirukan lafalan penulis dengan melafalkannya secara bersama-sama. Proses kegiatan ini dilakukan berulang-ulang oleh penulis agar siswa termotivasi belajar English pronunciation sehingga siswa akan mengalami adanya peningkatan dalam kemampuan di English pronunciation dan agar supaya tidak banyak terjadi kesalahan atau ketidaktepatan bunyi ketika melafalkan kata bahasa Inggris walaupun pada saat proses kegiatan ini sedang berlangsung, para siswa kelas satu awalnya sering salah dan tidak tepat saat melafalkan kata per kata bahasa Inggris ataupun saat melafalkan keseluruhan kata bahasa Inggris.

\section{Memotivasi Siswa Belajar Speaking}

Berbicara dengan menggunakan bahasa Inggris bagi siswa kelas satu MTS Qurrotul Uyun adalah sesuatu yang sangat jarang di praktikkan pada saat pelajaran bahasa Inggris 
sedang berlangsung. Ini di karenakan mereka tidak memilki perbendaharaan kosakata bahasa Inggris yang banyak, tidak memilki keberanian atau kepercayaan diri untuk speaking, sehingga mereka tidak memiliki motivasi untuk praktik speaking. Sehingga kemampuan speaking mereka buruk sekali. Untuk memotivasi para siswa kelas satu MTS Qurrotul Uyun belajar speaking, penulis memperlihatkan sebuah gambar warna dengan menggunakan power point seperti yang dapat di lihat pada Gambar 2. Dan penulis sengaja tidak memberikan kata-kata bahasa Inggris pada gambar tersebut dengan tujuan agar siswa termotivasi untuk mengartikan atau mendiskripsikan gambar tersebut dengan menggunakan kata - kata bahasa Inggris.

Gambar yang tanpa ada kata-kata bahasa Inggris tersebut ternyata dapat membuat kelas satu MTS Qurrotul Uyun antusias untuk belajar speaking, walaupun saat speaking mayoritas siswa menggunakan kata-kata bahasa Inggris yang di campur dengan katakata bahasa Indonesia (code mixing) seperti:

"orang sedang clean-clean sir",

"girl sedang nyapu",

"little perempuan sedang nyapu".

Setelah para siswa terlibat aktif berpartisipasi untuk speaking, dan di karenakan semua kata-kata yang mereka gunakan untuk mengartikan gambar tidak benar dan tidak full English, penulis kemudian menuliskan "The young girl is sweeping the floor" di whiteboard untuk memberitahukan pada siswa bahwa kata-kata tersebut adalah kata yang benar dan tepat untuk gambar tersebut. Kemudian penulis dengan jelas dan terang mengucapkan:

"The young girl is sweeping the floor"

dan menyuruh satu per satu siswa kelas satu untuk mempraktikkan untuk mengucapkan "The young girl is sweeping the floor" dengan jelas dan terang seperti yang telah di ucapankan oleh penulis.

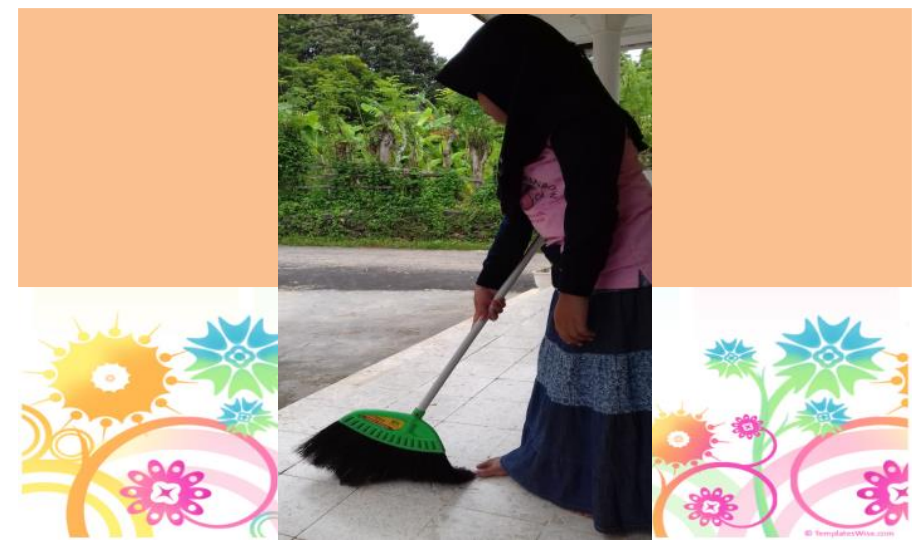

Gambar 2. Contoh Gambar Tanpa ada Kata-Kata Bahasa Inggris untuk Memotivasi Siswa Belajar Speaking

Aktifitas yang di lakukan oleh para siswa kelas satu MTS Qurrotul Uyun dalam mengartikan atau mendiskripsikan gambar memberikan dampak positif terhadap prilaku mereka. Tanpa mereka sadari, mereka yang sebelumnya enggan, malu dan malas untuk 
speaking, dengan melalui proses kegiatan ini mereka memilki rasa percaya diri dan keberanian saat mencoba untuk speaking.

\section{Memotivasi Siswa Belajar English Grammar}

Bahasa Indonesia dan bahasa Inggris mempunyai perbedaan pada aturan susunan tatabahasa kalimat, pada bagian-bagian linguistiknya, dan pada bentuk-bentuk kata kerjanya (Budiharto, 2018). Seperti bentuk kata kerja bahasa Inggris yang harus di tambahakan dengan akhiran ' $s$ ' atau 'es'jika subjeknya adalah orang ketiga tunggal di present tense (she, he, it), sedangkan bentuk kata kerja di bahasa Indonesia tidak mengenal tambahan akhiran 's' atau 'es apapun subjeknya. Atau bentuk kata kerja bahasa Inggris yang tidak beraturan (irregular verbs, seperti: go-went - gone) yang tidak di miliki di bentuk kata kerja bahasa Indonesia. Perbedaan - perbedaan ini merupakan salah satu faktor yang bisa menyebabkan siswa kelas satu MTS Qurrotul Uyun sangat kesulitan mempelajari dan memahami English grammar sehingga mereka tidak termotivasi untuk belajar English grammar. Untuk memotivasi mereka belajar English grammar, penulis memperlihatkan sebuah gambar warna dengan menggunakan power point seperti yang dapat di lihat pada Gambar 3.

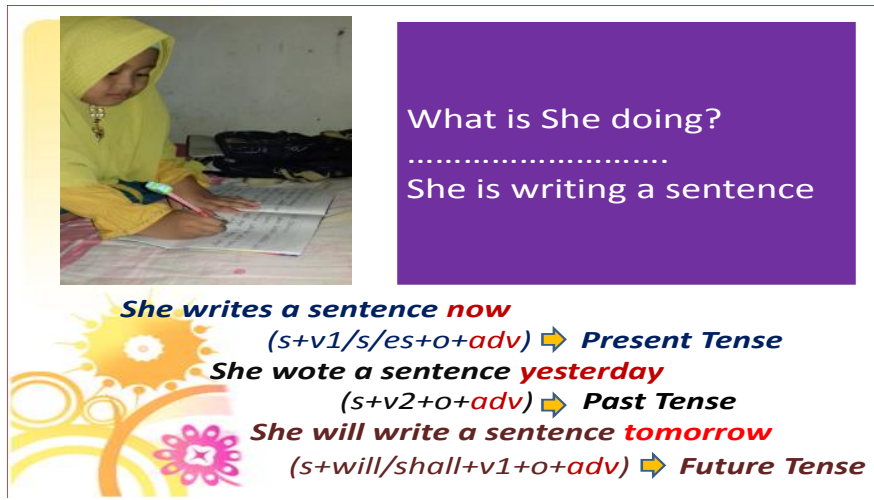

Gambar 3. Contoh Gambar untuk Memotivasi Siswa Belajar English Grammar

Gambar pertama kali yang diperlihatkan oleh penulis pada para siswa adalah gambar seorang anak perempuan yang sedang melakukan suatu aktifitas. Kemudian penulis memperlihatkan slide power point yang berisi pertanyaan "What is she doing?" dan menyuruh para siswa untuk menjawab pertanyaan tersebut dengan menggunakan susunan kalimat bahasa Inggris yang benar. Penulis memperlihatkan slide power point "She is writing a sentence" setelah para siswa tidak bisa menggunakan susunan tatabahasa kalimat bahasa Inggris yang benar ketika menjawab pertanyaan tersebut. Adapun contohcontoh jawaban kalimat siswa kelas satu yang tidak menggunakan English grammar:

"She write" (seharusnya "she write")

"Girl write letter" (seharusnya "a girl writes a letter)

"a woman writing" (seharusnya "a woman is writing)

Dan untuk lebih memudahkan pemahaman siswa terhadap English grammar pada kalimat dengan kata "write", penulis menulis perbedaan adverb of time untuk 3 tenses di whiteboard: "now" untuk present tense, "yesterday" untuk past tense dan "tomorrow" untuk future tense dan para siswa di suruh untuk memperhatikan dan memahami perbedaan penggunaan tiga adverb of time tersebut. Kemudian penulis menyuruh siswa 
untuk membuat kalimat positif dengan kata "write" dengan menggunakan 3 tenses: present, past dan future tense. Setelah para siswa terlibat aktif dalam membuat kalimat positif dengan kata "write" dengan menggunakan 3 tenses dan dikarenakan kalimat yang di buat oleh mereka tidak tepat dengan English grammar, penulis kemudian memperlihatkan slide power point yang berisi tiga susunan kalimat positif dengan kata "write" dengan menggunakan tiga (3) tenses beserta pola-polanya seperti yang dapat di lihat pada Gambar 3. Penulis juga memberikan pengetahuan tentang bentuk-bentuk kata kerja yang di gunakan pada 3 tenses tersebut agar para siswa mudah untuk mengingat ciri-ciri pokok pada tiap-tiap tenses tersebut. Seperti Verb bentuk pertama (1) di present tense di beri akhiran s/es jika subjeknya orang ke tiga tunggal (she, he, it), verb bentuk ke 2 di gunakan untuk past tense dan di gunakan untuk semua subjek (i, you, we, they, she, he, it), dan auxiliary verbs: will or shall + verb bentuk 1 di gunakan untuk future tense.

\section{SIMPULAN}

Penggunaan visual literacy melalui gambar merupakan alat pedagogik yang dapat memotivasi dan dapat menarik perhatian dan konsentrasi siswa kelas satu MTS Qurrotul Uyun saat belajar bahasa Inggris. Siswa kelas satu MTS Qurrotul Uyun merasa bahwa pembelajaran bahasa Inggris di kelas lebih menarik dan menyenangkan ketika mereka di terangkan dengan memberikan gambar sebagai visual aids nya, karena gambar tersebut dapat menarik perhatian pikiran mereka dan memudahkan mereka dalam belajar. Dan dengan melalui gambar, siswa kelas satu MTS Qurrotul Uyun lebih berpartisipasi dan lebih terlibat aktif dalam pembelajaran bahasa Inggris.

\section{REFERENSI}

Budiharto, R. A. (2018). Native language interference on target language writings of Indonesian EFL students: An Exploratory case study. Indonesian EFL Journal, 5(1), $107-116$.

Burmark, L. (2002). Visual literacy: Learn to see, see to learn. Alexandria, VA: Association for Supervision and Curriculum Development.

Cook, V. (2000). Linguistics and second language acquisition. Beijing: Foreign Language Teaching and Research Press and Macmillan Publishers Ltd.

Harris, I., \& Caviglioli, O. (2003). Think it - Map it!. Stafford: Network Educational Press.

Yenawine, P. (2005). Thoughts on visual literacy. In J. Flood, D. Lapp \& S. B. Heath (Eds.), Handbook of Research on Teaching Literacy Through the Communicative and Visual Arts. London: Routledge. 